Kresna Social Science and Humanities Research

Proceedings of the International Conference On Ummah:

Digital Innovation, Humanities And Economy (ICU: DIHEc) 2020

https://doi.org/10.30874/ksshr.9

\title{
Applying VUCA Prime to the Strategic Planning of Development Programs
} based on Needs Assessment

\author{
1st Wiwik Afridah ${ }^{1}$, 2nd Ubaidillah Zuhdi ${ }^{2}$, \\ (wiwik@unusa.ac.id ${ }^{1}$, ubaidillah.zuhdi@unusa.ac.id²) \\ Universitas Nahdlatul Ulama Surabaya, Jl. Jemursari 51-57 Surabaya ${ }^{1,2}$
}

\begin{abstract}
The strategic planning made by Universitas Nahdlatul Ulama Surabaya (UNUSA) in the second period (2018-2022) is purposed to become a leading university supported by reliable and wellestablished human resources. 143 out of 183 lecturers do not have any academic ranks. To answer the problem, the human resource department (HRD) has conducted several programs to accelerate the acquisition of those ranks. However, it is still questionable whether the programs can develop their competence and how the HRD builds their capacity based on the quality standards targeted by the internal quality assurance system (SPMI). Therefore, this study aims to set the strategic planning to develop the capacity of UNUSA lecturers in the era of VUCA (Volatility, Uncertainty, Complexity, Agility) using the VUCA Prime strategy (Vision, Understanding, Clarity, and Agility). Facing the VUCA era has become a new normal which certainly cannot be treated with oldfashioned styles. By using the Key Performance Indicators (KPI) set and adjusted with the VUCA Prime strategy and combined with 6 competencies (6 Cs) (Think Critically, Communicate Clearly, Work Collaboratively, Embrace Culture, Develop Creativity and Utilize Connectivity), this study is expected to be able to develop the capacity of UNUSA lecturers. The results will be used as a reference to set UNUSA strategic planning in the third period (2022-2026) purposed to prepare UNUSA transformation into excellent entrepreneurship university and to give the contribution to 100 years of Nahdlatul Ulama in increasing the capacity building.
\end{abstract}

Keywords: strategic planning, VUCA, VUCA Prime

\section{Introduction}

Universitas Nahdlatul Ulama Surabaya (UNUSA), one of the universities in Indonesia that has been operating since 2013, is required to consistently improve the quality of educational process and increase its relevance with the global competition. To achieve the long-term vision targeted in 2030, UNUSA has set the stages to achieve the vision as to become the leading university in the provincial level (in 2018), national level (in 2022), regional level (in 2026), and international level (in 2030) through the long-term development programs in the period of 2018 2022 aimed at becoming a university with competitive ability toward entrepreneurship expertise 
Proceedings of the International Conference On Ummah:

Digital Innovation, Humanities And Economy (ICU: DIHEc) 2020 https://doi.org/10.30874/ksshr.9

university in the national level.

The challenge faced by UNUSA in performing Tridharma Perguruan Tinggi (The Three Pillars of Higher Education) needs strategic planning to determine the programs to be carried out and predict the allocation of resources. The strategic planning is formulated to answer the current and future organizational problems (1) To design a good strategic planning requires an ability to identify problems, formulate strategies and face the new challenges by involving critical thinking in decision making. In this stage, capacity building or capacity development is needed (2) Retno Dewi Sulistiyowati (2020) claimed that capacity building is certainly not only oriented toward human ability, but it also covers the whole aspects of organization comprising of organization management system well known as management system, target achievement policy, achievement strategy and rules of organization (2).

According to the data stated by the Directorate General of Resources for Science, Technology, and Higher Education (Kemenristekdikti), Indonesia has only approximately 5.389 professors. In fact, the ideal requirement for professors in this country is 22.000 (3). It has been a big challenge for the higher education, especially for the lecturers in efforts to develop their capacity and ability as stated in the ministerial decree issued by Kemenristekdikti no. 44 of 2015 about the national standards for higher education (Permenristekdikti SNPT) and the law no. 12 of 2012 about higher education (UU-PT). The developing number of lecturers in Kemenristekdikti based on the academic ranks dated 3 September 2017 is described as follows:

\section{PERKEMBANGAN JUMLAH DOSEN DI LINGKUNGAN KEMRISTEKDIKTI BERDASARKAN JABATAN FUNGSIONAL DOSEN}

Data per tanggal 3 September 2017

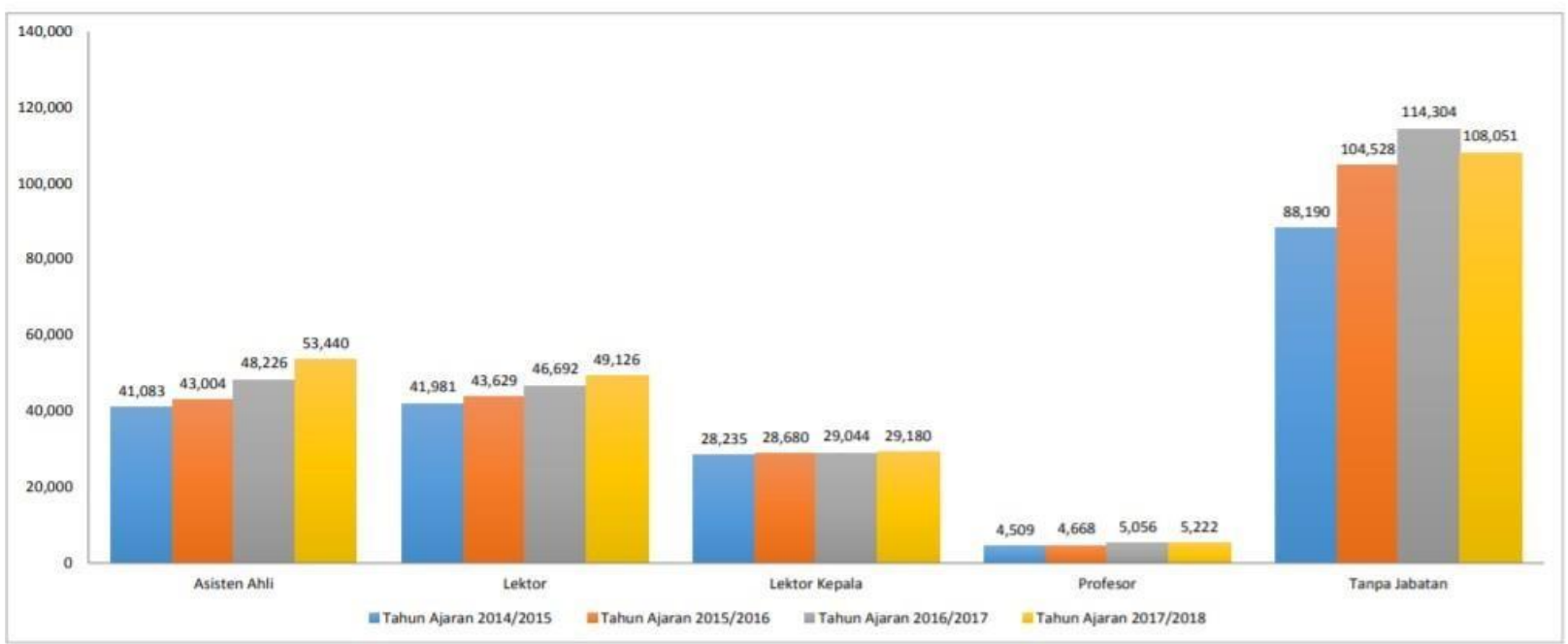




\section{Kresna Social Science and Humanities Research}

Proceedings of the International Conference On Ummah:

Digital Innovation, Humanities And Economy (ICU: DIHEc) 2020

https://doi.org/10.30874/ksshr.9

Source: Kemenristekdikti, 2017

Figure 1. Development of number of lecturers in Indonesia

ISSN 2774-3918 (online), https://ksshr.kresnanusantara.co.id. Published by Kresna Nusantara

Copyright (C) Author(s). This is an open-access article distributed under the terms of the Creative Commons Attribution License (CC BY).

To view a copy of this license, visit https://creativecommons.org/licenses/by/4.0/. 
Proceedings of the International Conference On Ummah: Digital Innovation, Humanities And Economy (ICU: DIHEc) 2020 https://doi.org/10.30874/ksshr.9

The same condition also happens at UNUSA in which 2016 is the starting point for proposing the academic ranks under the consideration that two years after its operation starting in 2013, the lecturers of UNUSA having conducted Tridharma activities are eligible to acquire the academic ranks. Table 1 below presents the data of academic ranks obtained by UNUSA lecturers.

Table 1. Data of academic ranks obtained by UNUSA lecturers, 2016

\begin{tabular}{|c|c|c|c|c|c|c|c|}
\hline \multirow[t]{2}{*}{ FACULTY } & \multirow[t]{2}{*}{ STUDY PROGRAM } & \multicolumn{5}{|c|}{ ACADEMIC RANK } & \multirow{2}{*}{$\begin{array}{l}\text { NUMBER OF } \\
\text { LECTURER }\end{array}$} \\
\hline & & Lecturer & $\begin{array}{l}\text { Lower } \\
\text { Assistant } \\
\text { Professor }\end{array}$ & $\begin{array}{l}\text { Upper } \\
\text { Assistant } \\
\text { Professor }\end{array}$ & $\begin{array}{l}\text { Associate } \\
\text { Professor }\end{array}$ & Professor & \\
\hline \multicolumn{7}{|c|}{$\begin{array}{l}\text { FACULTY OF ECONOMY AND } \\
\text { BUSINESS (FEB) }\end{array}$} & 13 \\
\hline S1 & Management & 6 & 0 & 1 & 0 & 0 & 7 \\
\hline S1 & Accountancy & 6 & 0 & 0 & 0 & 0 & 6 \\
\hline \multicolumn{7}{|c|}{ FACULTY OF HEALTH (FKES) } & 34 \\
\hline S1 & Public Health & 8 & 2 & 0 & 0 & 0 & 10 \\
\hline S1 & Nutrition & 10 & 0 & 0 & 0 & 0 & 10 \\
\hline D4 & $\begin{array}{l}\text { Occupational Safety } \\
\text { and Health }\end{array}$ & 5 & 0 & 0 & 0 & 0 & 5 \\
\hline D4 & Healthcare Analytics & 9 & 0 & 0 & 0 & 0 & 9 \\
\hline \multicolumn{7}{|c|}{ FACULTY OF MEDICINE (FK) } & 40 \\
\hline S1 & Medicine & 39 & 0 & 1 & 0 & 0 & 40 \\
\hline \multicolumn{7}{|c|}{$\begin{array}{l}\text { FACULTY OF NURSING AND MIDWIFERY } \\
\text { (FKK) }\end{array}$} & 60 \\
\hline S2 & Applied Nursing & 1 & 5 & 0 & 0 & 0 & 6 \\
\hline Profession & Ners Program & 2 & 2 & 2 & 0 & 0 & 6 \\
\hline S1 & Nursing & 12 & 8 & 2 & 0 & 0 & 22 \\
\hline D3 & Nursing & 6 & 3 & 1 & 0 & 0 & 10 \\
\hline D3 & Midwifery & 10 & 6 & 0 & 0 & 0 & 16 \\
\hline \multicolumn{7}{|c|}{$\begin{array}{l}\text { FACULTY OF TEACHER TRAINING AND } \\
\text { EDUCATION (FKIP) }\end{array}$} & 27 \\
\hline S1 & $\begin{array}{l}\text { Early Childhood } \\
\text { Education }\end{array}$ & 10 & 2 & 0 & 0 & 0 & 12 \\
\hline S1 & $\begin{array}{l}\text { Elementary Teacher } \\
\text { Education }\end{array}$ & 9 & 0 & 0 & 0 & 0 & 9 \\
\hline S1 & English Education & 6 & 0 & 0 & 0 & 0 & 6 \\
\hline \multicolumn{7}{|c|}{$\begin{array}{l}\text { FACULTY OF } \\
\text { ENGINEERING (FT) }\end{array}$} & 9 \\
\hline S1 & Information System & 9 & 0 & 0 & 0 & 0 & 9 \\
\hline \multicolumn{2}{|l|}{$\begin{array}{l}\text { TOTAL } \\
\text { NUMBER }\end{array}$} & 148 & 28 & 7 & $\mathbf{0}$ & $\mathbf{0}$ & 183 \\
\hline
\end{tabular}

Source: Primary data, 2020

Data in table 1 describe that $148(80.87 \%)$ out of 183 lecturers have not acquired academic ranks yet. There are four ranks in the schema of career development in academic. The first rank is lower assistant professor. The second rank is upper assistant professor. The next rank is associate 


\section{Kresna Social Science and Humanities Research}

Proceedings of the International Conference On Ummah:

Digital Innovation, Humanities And Economy (ICU: DIHEc) 2020

https://doi.org/10.30874/ksshr.9

professor. Finally, the highest rank is professor.

ISSN 2774-3918 (online), https://ksshr.kresnanusantara.co.id. Published by Kresna Nusantara

Copyright (C) Author(s). This is an open-access article distributed under the terms of the Creative Commons Attribution License (CC BY).

To view a copy of this license, visit https://creativecommons.org/licenses/by/4.0/. 


\section{Kresna Social Science and Humanities Research}

Proceedings of the International Conference On Ummah:

Digital Innovation, Humanities And Economy (ICU: DIHEc) 2020

https://doi.org/10.30874/ksshr.9

Human resources, especially the lecturers play important roles in the continuity of educational process in a university so that special strategies are needed to accelerate the acquisition of academic ranks by building an internal credit point assessor team assigned to assess the lecturers' proposals for academic ranks before being sent to Siladikti LLDIKTI VII (Higher Education Services). The team will do the jobs using a method, called VUCA Prime. Considering the minimum use of VUCA Prime in studies conducted in universities, this study focuses on the use of the method to play an important role in solving problems dealing with the acquisition of academic ranks.

VUCA was proposed in 1987 to describe the leadership theories by Warren Bennis and Burt Nanus. U.S. Army War College used VUCA concept to describe the conditions which were unstable (volatility), uncertain (uncertainty), complex (complexity), and unclear (ambiguity) resulted from the cold war. This definition was then adopted by the figures in business strategy to describe the rapidly changing business environment which has become the new normal (Kinsinger \& Walch, n.d.) (2).

Eillen Rachman and Billy Latuptty (Character Building and Training) through their writing entitled "Te New Normal" stated that "...we are entering continuous VUCA condition: volatility (rapidly, great and dynamic change), uncertainty (when we cannot predict the situation), complexity (various overlapping issues that possibly cause a chaos), and ambiguity (when the reality looks hazy and hard to interpret). Some years ago, we used to perceive that the world was full of problems, demands, rapidness, and analysis. Currently, it is full of dilemma so that patience, sense-making and engagement are needed more. Finally, the world with VUCA which looks uncomfortable and full of surprises can be transformed into adaptive VUCA, namely vision - the belief that we can create our own future, understanding - the power to stop, look, and listen, clarity - the ability to understand and stand tall (survive) in chaos, and agility - replacing hierarchies with linkages and networks" (Gozali, 2017)(2).

This study aims to set the strategic planning for developing the capacity of UNUSA lecturers in VUCA era (Volatility, Uncertainty, Complexity, Agility) by using VUCA Prime strategy (Vision, Understanding, Clarity, and Agility) combined with 6 competencies or 6 Cs (Think Critically, Communicate Clearly, Work Collaboratively, Embrace Culture, Develop Creativity and Utilize Connectivity). The results will be used as a reference for UNUSA strategic planning in the third period of 2022-2026 toward an excellent entrepreneurship university and as 


\section{Kresna Social Science and Humanities Research}

Proceedings of the International Conference On Ummah:

Digital Innovation, Humanities And Economy (ICU: DIHEc) 2020

https://doi.org/10.30874/ksshr.9

the contribution to 100 years of Nahdlatul Ulama.

\section{Method}

This study was an operational research aimed at providing solutions to operational problems in carrying out programs or activities in which the results were used to solve problems by maintaining the use of scientific methods. The definition of operational research, according to Hamdi A. Taha, is an approach for decision making characterized by the use of scientific knowledge through the efforts of multidisciplinary groups purposed to determine the use of the best and limited resources. Deep interview was conducted in June 2020 by the credit point assessor team (PAK team). The information provided for this study is obtained from the informants, namely the coordinator of PAK team, Human Resources sub-division and all members of UNUSA PAK team through in-depth interviews. To obtain valid and reliable data, triangulation was conducted by collecting primary and secondary data and comparing information / data through observations of situations in different perspectives. Moreover, the data were processed by reading transcription accurately and completely. Finally, data analysis was conducted using VUCA lens 1) to find determinant indicators in strategic planning, 2) to find factors affecting strategic planning and provide understandable results for setting the next strategic planning.

\section{Result}

The mechanism for assessing the academic rank of lower and upper assistant professor was conducted by the credit point assessor team (PAK team) based on the ministerial decree of Permendikbud No. 92 of 2014 about the credit point assessment technical guidelines for academic ranks and the credit points (Permendikbud RI-PAK)(4) in each state universities which is different from the mechanism for assessing academic ranks conducted by the Directorate General of Resources for Science, Technology, and Higher Education (Kemenristekdikti) (3). To acquire lower and upper assistant professor, the credit points of the state university lecturers were assessed by the credit point assessor team from their own universities. On the other hand, the credit points of the private university lecturers were assessed by the credit point assessor team from Kopertis (Coordinator of Private Higher Education). Whilst, the promotion to associate professor and professor for both state and private university lecturers in Kemenristekdikti and other ministries / institutions was conducted by the credit point assessor team from the Directorate General of Resources for Science, Technology, and Higher Education (Kemenristekdikti). 


\section{Kresna Social Science and Humanities Research}

Proceedings of the International Conference On Ummah:

Digital Innovation, Humanities And Economy (ICU: DIHEc) 2020

https://doi.org/10.30874/ksshr.9

Each university is expected to have a good understanding to easily determine the strategy for problem solving when accelerating the promotion of academic ranks. UNUSA has prepared it by building the credit point assessor team having been doing the duties since 11 February 2016 based on the decree issued by the rector No. 232/UNUSA/Adm-SK/II/2016 comprising of 1 educative staff representing each faculty, whereas the non-educative staff is represented by the staff from the Human Resource Department, totaling 12 members including the rector and vice rector I and II.

Activities conducted by the assessor team were as follows: (a) to provide socialization program for all lecturers about the importance of academic ranks in collaboration with LLDIKTI, (b) to provide direct technical guidance to the lecturers as a personal approach, (c) to provide special socialization and guidance in the Faculty of Medicine aimed at building the same perception for doctors who have just joined the educative staff, (d) to set the guidelines for internal credit point assessment with its style guide adjusted with the culture of UNUSA lecturers as well as to provide a sample showing how to fill out the proposal of credit point assessment (DUPAK), (e) to collaborate with the library unit and LPPM (Research and Community Service Institution) concerning with the technical problems found when filling out the proposal with the correct data to fulfill the requirements (f) to hold academic senate meetings (once a month) to discuss the submitted proposals, (g) to map the academic ranks of the lecturers in each faculty regularly, and (h) to give the lecturers a notification letter to encourage them to make the proposals. Graphic 1 below illustrates the proposal of credit point assessment at UNUSA. 


\section{Kresna Social Science and Humanities Research}

Proceedings of the International Conference On Ummah: Digital Innovation, Humanities And Economy (ICU: DIHEc) 2020 https://doi.org/10.30874/ksshr.9

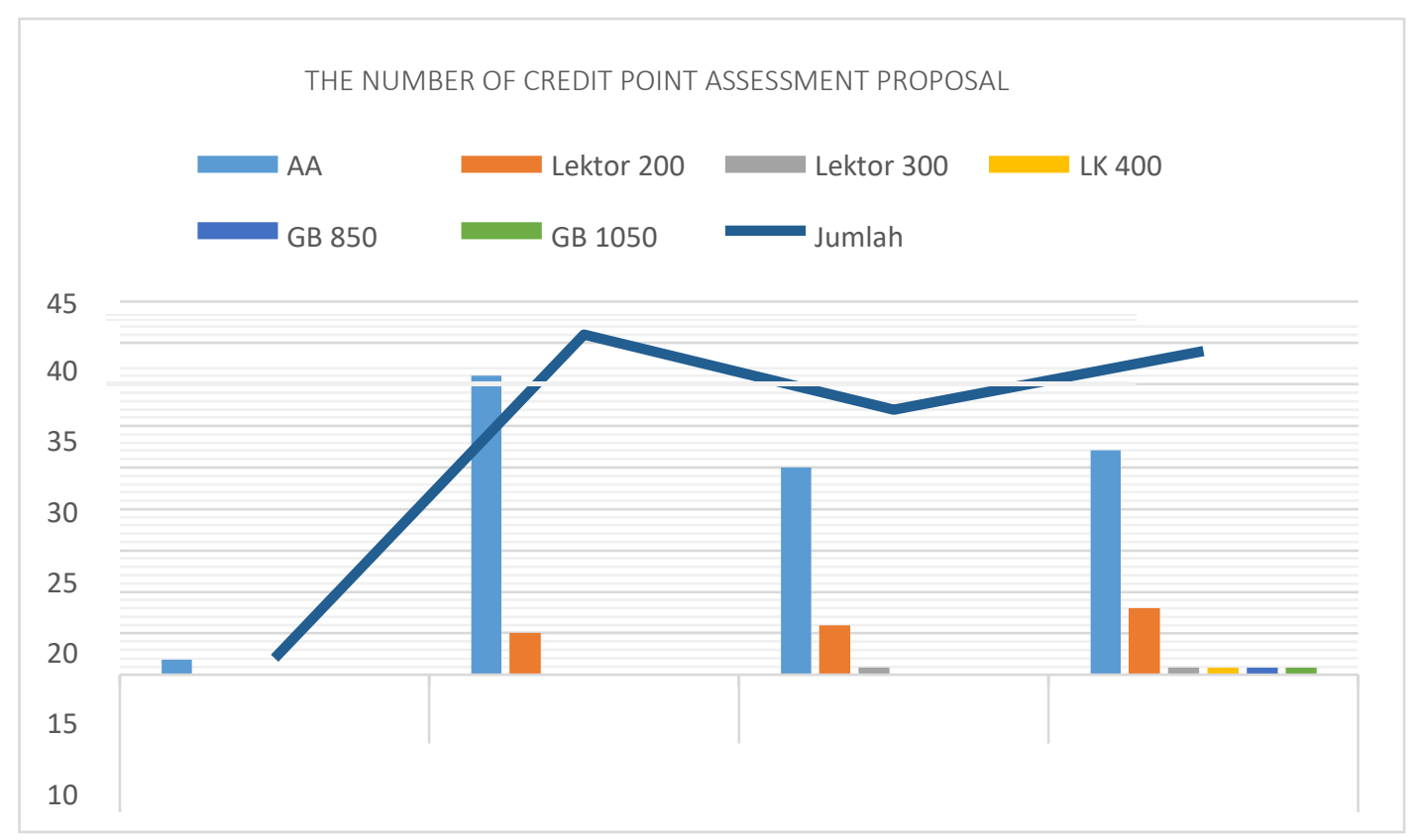

Graphic 1. Credit Point Assessment Proposal
AA (lower assistant professor)
LK (associate professor)
Lektor (upper assistant professor)
GB (professor)

The proposal described in graphic 1 is clearly explained in table 2 below:

\begin{tabular}{lllll}
\hline Academic Ranks & \multicolumn{3}{l}{$\begin{array}{l}\text { Year of Proposal } \\
\text { Submission }\end{array}$} \\
\cline { 2 - 5 } & 2017 & 2018 & 2019 & 2020 \\
\hline Lower Assistant Professor & 2 & 36 & 25 & 27 \\
Upper Assistant Professor 200 & 0 & 5 & 6 & 8 \\
Upper Assistant Professor 300 & 0 & 0 & 1 & 1 \\
Associate Professor 400 & 0 & 0 & 0 & 1 \\
Professor 850 & 0 & 0 & 0 & 1 \\
Professor 1050 & 0 & 0 & 0 & 1 \\
\hline Total & $\mathbf{2}$ & $\mathbf{4 1}$ & $\mathbf{3 2}$ & $\mathbf{3 9}$ \\
\hline
\end{tabular}

The successful increase of achieving academic ranks at UNUSA from 2017 until 2020 is illustrated in table 3 below:

Table 3. Successful increase of achieving academic ranks in $2017-2020$ 


\begin{tabular}{|c|c|c|c|c|c|c|}
\hline \multirow[t]{2}{*}{ FACULTY } & NUMBER & \multicolumn{4}{|c|}{ ACADEMIC RANKS } & \multirow{2}{*}{$\begin{array}{l}\text { TOTAL } \\
\text { NUMBER }\end{array}$} \\
\hline & & $\begin{array}{l}\text { Lower } \\
\text { Assistant } \\
\text { Professor }\end{array}$ & $\begin{array}{l}\text { Upper } \\
\text { Assistant } \\
\text { Professor }\end{array}$ & $\begin{array}{l}\text { Associate } \\
\text { Professor }\end{array}$ & $\begin{array}{l}\text { Profes } \\
\text { sor }\end{array}$ & \\
\hline ECONOMY AND BUSINESS & 13 & & & & & 11 \\
\hline 2017 & & 1 & 0 & 0 & 0 & 1 \\
\hline 2018 & & 3 & 0 & 0 & 0 & 3 \\
\hline 2019 & & 4 & 0 & 0 & 0 & 4 \\
\hline 2020 & & 1 & 1 & 1 & 0 & 3 \\
\hline HEALTH & 34 & & & & & 22 \\
\hline 2017 & & 1 & 0 & 0 & 0 & 1 \\
\hline 2018 & & 10 & 1 & 0 & 0 & 11 \\
\hline 2019 & & 6 & 0 & 0 & 0 & 6 \\
\hline 2020 & & 4 & 0 & 0 & 0 & 4 \\
\hline MEDICINE & 40 & & & & & 15 \\
\hline 2017 & & 0 & 0 & 0 & 0 & 0 \\
\hline 2018 & & 0 & 0 & 0 & 0 & 0 \\
\hline 2019 & & 7 & 0 & 0 & 0 & 7 \\
\hline 2020 & & 7 & 0 & 0 & 1 & 8 \\
\hline $\begin{array}{l}\text { NURSING AND } \\
\text { MIDWIFERY }\end{array}$ & 60 & & & & & 34 \\
\hline 2017 & & 0 & 0 & 0 & 0 & 0 \\
\hline 2018 & & 10 & 3 & 0 & 0 & 13 \\
\hline 2019 & & 3 & 5 & 0 & 0 & 8 \\
\hline 2020 & & 5 & 7 & 0 & 1 & 13 \\
\hline $\begin{array}{l}\text { TEACHER TRAINING AND } \\
\text { EDUCATION }\end{array}$ & 27 & & & & & 25 \\
\hline 2017 & & 0 & 0 & 0 & 0 & 0 \\
\hline 2018 & & 10 & 1 & 0 & 0 & 11 \\
\hline 2019 & & 5 & 0 & 0 & 0 & 5 \\
\hline 2020 & & 8 & 1 & 0 & 0 & 9 \\
\hline ENGINEERING & 9 & & & & & 7 \\
\hline 2017 & & 0 & 0 & 0 & 0 & 0 \\
\hline 2018 & & 2 & 0 & 0 & 0 & 2 \\
\hline 2019 & & 2 & 0 & 0 & 0 & 2 \\
\hline 2020 & & 2 & 1 & 0 & 0 & 3 \\
\hline TOTAL NUMBER & 183 & 91 & 20 & 1 & 2 & 114 \\
\hline
\end{tabular}

Primary data: June 2020

The increasing number of lecturers obtaining academic ranks is $62.30 \%$ described in the following details: out of 148 lecturers having no academic ranks, 91 of them have successfully acquired lower assistant professor (61.49\%). Lecturers with lower assistant professor have been promoted to upper assistant professor (71.43\%). Those with upper assistant professor have acquired associate professor (14.29\%). Moreover, lecturers with associate professor have been promoted to professor $(28.57 \%)$. 


\section{Kresna Social Science and Humanities Research}

Proceedings of the International Conference On Ummah:

Digital Innovation, Humanities And Economy (ICU: DIHEc) 2020

https://doi.org/10.30874/ksshr.9

The significant increase happened in three non-medical faculties: Economy and Business (84.62\%), Teacher Training and Education (92.59), and Engineering (77.78\%). The achievement was also made by three medical faculties: medicine (37.50\%), health (64.71\%), and Nursing and Midwifery (56.60\%).

While doing the duties, the credit point assessor team found some problems, mainly in the four sub divisions: education, research, community services, and supporting components.

\section{A. Education}

Based on the result of interviews, this study found that there has been a stagnant increasing number in promoting the lecturers with upper assistant professor and associate professor due to the high workload in teaching which causes them to focus more energy and concentration on teaching activities. Besides, they also had to function themselves as the student's advisors, such as academic advisor, apprentice advisor, and thesis advisor. Furthermore, extra duties as deans, vice deans, and heads of study program also brought them problems in allocating their time for conducting research and community services.

B. Research

High workload in teaching also became an obstacle in conducting research as an intellectual quality work of the lecturers. This study found three problems in conducting research, such as the ability and motivation of the lecturers to conduct a research, write the report and produce a scientific work to meet the requirements for proposing academic ranks, institution's supports of facilities, accompaniment, socialization, and funding.

C. Community service

Based on the standard lecturer's workload (BKD), each lecturer is required to conduct community services once at minimum in one academic year reported at the end of the year. This study found no problem because the institution has provided them with financial support managed by LPPM. However, the final results (outputs) of this activity have not been published in both internal and external journals.

D. Supporting components

The supporting division covers the lecturers' activities outside teaching, research, and community services which contribute directly to the development of faculty / university, such as the involvement as members or holding positions in the committee of accreditation program. UNUSA has declared the year of 2016 as the lively year of accreditation because 


\section{Kresna Social Science and Humanities Research}

Proceedings of the International Conference On Ummah:

Digital Innovation, Humanities And Economy (ICU: DIHEc) 2020

https://doi.org/10.30874/ksshr.9

all of the study programs participated in the agenda. Because 10 out of 14 study programs newly operated in 2013, they must have received accreditation certificates in 2017 . On the other hand, the four existing study programs have been in consecutive visitation process.

\section{Discussion}

The results of assessment was in line with the concept proposed by Scott (2001) that strengthening the institution needs to focus on three levels, namely human resources development, organizational strengthening and institutional reform. Human resources development is related to individual development in organization. Organizational strengthening is related to organizational management system (3). Andrews (1980) also claimed that strategic management is dominated by the goals, consideration about the opportunities and attention to the needs (5).

Moore (2014) explained that strategic management overlaps between (1) strategic planning which provides an understanding that strategy functions as integration or organization compatibility (2) strategy making which is a process of how strategy is made to respond the complexities and increasing dynamics (3) strategic thinking which shows the necessity of strategic thinking to suggest that strategic thinking gives questions and answers which depend on executive strategic thinking, as described in figure 1 below:

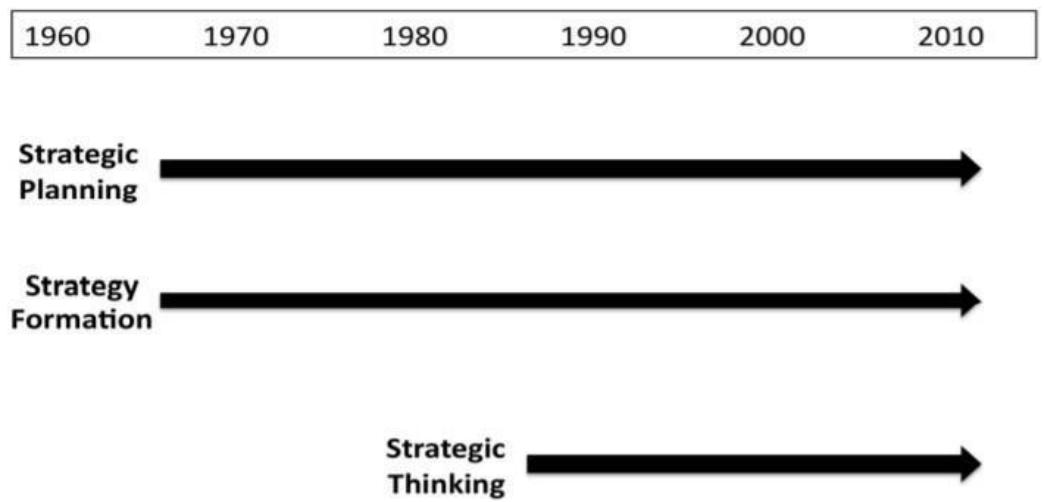

Figure 2.1. Corporate strategy research and attention.

Figure 1 Strategic Development

Selznick (1957) explained about attention which is focused on developing strategy by making use of internal and external environment and pursuing different competencies.

The strategy priority formulized to face the era of VUCA (Volatility, Uncertainty, ISSN 2774-3918 (online), https://ksshr.kresnanusantara.co.id. Published by Kresna Nusantara 


\section{Kresna Social Science and Humanities Research}

Proceedings of the International Conference On Ummah:

Digital Innovation, Humanities And Economy (ICU: DIHEc) 2020

https://doi.org/10.30874/ksshr.9

Complexity, and Ambiguity) is VUCA Prime (Vision, Understanding, Clarity, and Agility).

1) Vision: a strong vision functions as a basis to face the rapid and dynamic changes (volatility)

2) Understanding: a strong vision also helps the leader to change uncertainty to understanding. This will lead all team members to have the same mindset and build mutual understanding which brings a contribution to the success of organization.

3) Clarity: organization maintains mutual commitment for simplicity so that complexity can be changed into clarity.

4) Agility: it is necessary to possess agility when facing each change or responding to a new rapid development. Agility can overcome ambiguity when responses are received

immediately. Being late in making changes, understanding changes and doing actions will result in losing directions or the efforts will not be contextual anymore.

The four major agents in the process of achieving academic ranks involving the credit point assessor team are lecturer, faculty, university and LLDIKTI (Higher Education Services). A lecturer must prepare the documents to fulfill all the requirements. The faculty and university prepare the right pattern to accelerate the increasing number of lecturers to obtain the lowest academic ranks by giving the highest priority to the lecturers pursuing lower assistant professor despite those pursuing upper assistant professor, associate professor and professor. On the other hand, LLDIKTI is the institution which has an authority to determine the eligibility of the lecturers according to the policy which frequently experiences some changes.

The adjustment to each change in the policy dealing with the completeness of documents is the main duty of the credit point assessor team which should give personal advices. To face the unclear conditions (ambiguity), the 6 Cs (Think Critically, Communicate Clearly, Work Collaboratively, Embrace Culture, Develop Creativity and Utilize Connectivity) are required through accompaniment program conducted by the assessor team, starting with the process of filling out the proposal sheets, submitting documents related to the credit points of Tridharma Perguruan Tinggi, and preparing all physical evidences in soft files. It is a part of strategies to increase the participation in career development. Furthermore, the team should re-check the data before submitting the proposal to the dean for approval. Therefore, the team should be selective to assess the proposal and all the supporting documents to avoid plagiarism. 


\section{Kresna Social Science and Humanities Research}

Proceedings of the International Conference On Ummah:

Digital Innovation, Humanities And Economy (ICU: DIHEc) 2020

https://doi.org/10.30874/ksshr.9

The assessor team invites each actor to have 6 Cs which can be described as follows:

1) Think Critically (critical thinking): Critical thinking starts with the culture of asking question (Who - What - Where - When - Why - and How / 5Ws \& 1H). The assessor team is a an example of team with good critical thinking because its members are required to find the root problem by making Root Cause Analysis (RCA), chronology, and other factors during proposal submission process.

2) Communicate Clearly: Identifying the quality of document filing by providing mutual effective communication is the main requirement.

3) Work Collaboratively: Collaboration is a continuing process which involves effective dialogues with the lecturers pursuing academic ranks by asking questions and training to think critically without expecting immediate answers.

4) Embrace Culture: The ability to adjust to and modify the specific culture leads to the increasing results.

5) Develop Creativity: Deconstructing the creativity and critical thinking becomes an important component to support the development of high quality feedbacks (7).

6) Utilize Connectivity: The structure of organizational communication affects the characteristics of interactions which can lead to competitive superiority. On the other hand, social interactions among individuals in an organization are also beneficial to produce positive feedbacks (8).

\section{Conclusion and Suggestion}

VUCA Prime strategy (Vision, Understanding, Clarity, and Agility) combined with 6 Cs (Think Critically, Communicate Clearly, Work Collaboratively, Embrace Culture, Develop Creativity and Utilize Connectivity) can be used as an alternative strategy to overcome problems dealing with the efforts in promoting the academic ranks which happen because of the non-optimal critical thinking and effective communication. VUCA Prime strategy applied in promoting academic ranks which should be used as the reference for the Key Performance Index (KPI) to set the strategic planning in the third period $(2022-2026)$ is the manifestation of UNUSA to prepare excellent entrepreneurship university and the dedication to 100 years of Nahdlatul Ulama in facing disruptive era. 


\section{Kresna Social Science and Humanities Research}

Proceedings of the International Conference On Ummah:

Digital Innovation, Humanities And Economy (ICU: DIHEc) 2020

https://doi.org/10.30874/ksshr.9

\section{REFERENCES}

1. Syahrul. Perencanaan Strategis dan Praktik .... Shautut Tarb. 2017;36:1-18.

2. Sulistyowati RD. SDM Divisi Keperawatan RS Awal BROS Bekasi Tahun 2020 - 2024. 2020; Universitas Indonesia

3. Amelia MRKM dan A, Fakultas. Strategi Percepatan Peningkatan Jabatan Fungsional Dosen ( Studi Pada Fakultas X Universitas Y ) the Strategy of Acceleration Improvement of Lecturer' S Academic Ranks ( Study the Faculty of X , Y University ). 2019;47-60.

4. Kemendikbud. Pedoman Operasional Penilaian Angka. 2019.

5. Moore D. The experience of strategic thinking in a volatile, uncertain, complex and ambiguous (VUCA) environment.2014;(June1982):278:https://search.proquest.com/openview/c1a722113276 5c5fab6d96b8098d 0f2e/1?pq-origsite $=$ gscholar\&cbl=18750\&diss $=\mathrm{y}$

6. Horth D, Buchner D. Innovation Leadership: How to use innovation to lead effectively, work collaboratively and drive results. Cent Creat Leadersh. 2014;20.

7. Shively K, Stith KM, Rubenstein LDV. Measuring What Matters: Assessing Creativity, Critical Thinking, and the Design Process. Gift Child Today. 2018;41(3):149-58.

8. Koohborfardhaghighi S, Lee DB, Kim J. How different connectivity patterns of individuals within an organization can speed up organizational learning. Multimed Tools Appl. 2017;76(17):17923-36. 
Kresna Social Science and Humanities Research

Proceedings of the International Conference On Ummah:

Digital Innovation, Humanities And Economy (ICU: DIHEc) 2020

https://doi.org/10.30874/ksshr.9

ISSN 2774-3918 (online), https://ksshr.kresnanusantara.co.id. Published by Kresna Nusantara

To view a copy of this license, visit https://creativecommons.org/licenses/by/4.0/. 